\title{
Reproductive Toxicity of Chronic Exposure To Polystyrene Microplastics And The Molecular Mechanism of Decrease In Testosterone Levels In Male Mice
}

Haibo Jin

Nanjing University

Minghao Yan

Nanjing University

Chun Pan

Nanjing University

Zhenyu Liu

Nanjing University

Xiaoxuan Sha

Nanjing University

Chengyue Jiang

Nanjing University

Luxi Li

Nanjing University

Mengge Pan

Nanjing University

Dongmei Li

Nanjing University

Xiaodong Han

Nanjing University

Jie Ding ( $\nabla$ djie@nju.edu.cn )

Nanjing University

\section{Research Article}

Keywords: PS-MPs, Reproductive toxicity, Testosterone, LHR

Posted Date: July 19th, 2021

DOI: https://doi.org/10.21203/rs.3.rs-689230/v1 
License: (c) (i) This work is licensed under a Creative Commons Attribution 4.0 International License. Read Full License 


\section{Abstract}

Background: Microplastics (MPs), which are smaller in size and difficult to degrade, can be easily ingested by marine life and enter mammals including human through the food chain. Previous study has demonstrated that acute exposure to MPs induced a reduction of testosterone levels and finally resulted in male reproductive toxicity. Therefore, assessing the harm that MPs dose to the male reproductive system under long-term exposure of environmental concentrations and comprehending the mechanism from cell and molecular

levels are necessary.

Results: We affirmed that male reproductive toxicity of chronic exposure to polystyrene MPs (PS-MPs) in environmental pollution concentrations and explored the underlying mechanism of MPs-induced decrease of testosterone in mice. Polystyrene MPs (PS-MPs) treatment resulted in the destruction of testicular histology, abnormal spermatogenesis, and interference of hormone secretion in serum. PS-MPs induced a reduction of testosterone levels through downregulation of LH-mediated LHR/CAMP/PKA/StAR pathway. Moreover, we discovered that PS-MPs attached to and became internalized by Leydig cells.

Conclusions: In summary, our study showed that PS-MPs existed toxicity to male reproduction under long-term exposure and environmental pollution concentrations, and these potential hazards may ring alarm bells of public health. As well, the discussing of molecular mechanisms may be instructive to search novel therapeutic targets.

\section{Background}

In recent years, the rapid development of the plastic industry leads to the serious pollution of plastic waste $[1,2]$. After wave action, UV radiation, photodegradation, and biodegradation, plastic waste is degraded into fragments and particles of different sizes [3, 4]. Microplastics (MPs), with diameters less than $5 \mathrm{~mm}$, have attracted broad attention $[5,6]$, because of their small size, stable chemical properties and difficulty in degradation [7]. In the wild, the main components of MPs are polyethylene terephthalate, polyethylene, polystyrene, polypropylene, and polyvinyl chloride [8, 9]. MPs may induce biological health hazard, due to it is tend to accumulate in organisms and cause toxicity. What is worse, MPs can be easily transported into food chains and ultimately threaten human health $[10,11]$. Therefore, it warns us to pay special attention to the toxicity of MPs.

Previous researches have demonstrated that MPs are harmful to multiple organs in aquatic organisms and mammals, such as liver, kidney, gastrointestinal tract, brain $[12,13,14,15,16,17,18,19,20,21]$. Reproductive system plays a crucial role in an organism. Reproductive toxicity of MPs has been found in aquatic organisms, such as Daphnia, Hydra attenuate [21], medaka fish [22], and oyster [23]. So far, there are not many studies on the reproductive toxicity of MPs to mammals. Researchers have demonstrated that MPs induced decreased sperm quality, disordered hormone levels, and oxidative stress in testis following acute and short-term exposure $[24,25,26]$. However, it is of practical significance to study the 
toxic effect of long-term exposure to MPs under environmental concentrations on reproductive system of mammals.

Our previous study identified that following exposure to PS-MPs for 28 days, the testosterone level in serum and sperm quality were declined, resulting in male reproductive dysfunctions in mice. Nevertheless, the underlying mechanism of the decrease in testosterone levels caused by MPs remains unexplored. Testosterone, the most important androgen in males, plays an important role in spermatogenesis. [27] Testosterone is synthesized and secreted by Leydig cells [28]. Meanwhile, the specific synthesis process is described below. LH, which is released by the anterior pituitary, binds to LH receptors (LHR) located on the membrane of Leydig cells, resulting in increased cAMP content. Then, protein kinase A (PKA) is activated and the levels of steroidogenic acute regulatory protein (StAR) and steroid synthase (P450scc, P450c17, 3 $\beta-H S D, 17 \beta-H S D)$ are increased. Under the action of StAR, free cholesterol in cytoplasm is transported from the outer membrane of mitochondria to the inner membrane. P450scc on the intima converts cholesterol into pregnenolone. Pregnenolone sequentially enters the endoplasmic reticulum, where it is converted to testosterone by $3 \beta-H S D, P 450 c 17$, and 17 $\beta-H S D$ [29]. A decreased testosterone level is strongly correlated with MPs-induced functional damage in the testes and Leydig cells.

In addition, previous studies reported that the toxicity of MPs in different tissues is closely related to its particle size. Deng et al. showed that $5 \mu \mathrm{m}$ and $20 \mu \mathrm{m}$ PS-MPs exposure induced disturbance of energy and lipid metabolism [16]. Jeong et al. demonstrated that $0.05 \mu \mathrm{m}, 0.5 \mu \mathrm{m}$, and $6 \mu \mathrm{m}$ PS-MPs treatment led to reduction in growth rate and fecundity, and pointed that the toxicity of MPs was size dependent and smaller microbeads were more poisonous [30]. Meanwhile, some researches elucidated that the toxicity of MPs is concentration dependent $[17,19,31]$. Therefore, we sought to investigate the effects of the different sizes and concentrations of MPs on the male reproductive system of mammals.

In present study, we exposed mice to MPs of different particle sizes $(0.5 \mu \mathrm{m}, 4 \mu \mathrm{m}$ and $10 \mu \mathrm{m})$ at different environmental concentrations to explore male reproductive toxicity of MPs. In addition, we used primary Leydig cells model to investigate the underlying mechanism of the decrease in testosterone levels induced by MPs. Our findings may provide a novel insight for preventing the reproductive toxicity of MPs.

\section{Results}

\section{Characterization of polystyrene microplastics (PS-MPS)}

Confocal imaging was conducted to detect the morphology and sizes of PS-MPs used in this study. As shown in Fig. 1A, the MPs were spheres and the sizes of MPs met the design requirements. According to Raman spectra analysis, the monomer of MPs is polystyrene (Fig. 1B). The zeta potential values were exhibited in Supplementary Table S3.

Exposure to PS-MPs induced testicular tissue structure damage and sperm quality decrease in mice 
During the period of treatment, we monitored the body weights, consumption of food and water. The body weights and food consumption of mice were decreased (Supplementary Table S4). However, there was no remarkable change on water intake among different groups. Compared with control group, the testicular coeffcient (Fig. 2A) and epididymal coefficient (Fig. 2B) decreased signifcantly in the $0.5 \mu \mathrm{m}, 4$ $\mu \mathrm{m}$, and $10 \mu \mathrm{m}$ group. Meanwhile, the testicular coefficient of $1000 \mu \mathrm{g} / \mathrm{L}$ PS-MPs with a diameter of 10 $\mu \mathrm{m}$ group decreased more obviously than that of $100 \mu \mathrm{g} / \mathrm{L}$ group. Following exposure to PS-MPs for 180 days, we detected the viability and morphology of sperms. Results revealed that PS-MPs exposure decreased the viability of sperm (Fig. 2C) and increased the rate of sperm deformity (Fig. 2D). In addition, we observed that PS-MPs induced derangement of cell layers and abscission of spermatogenic cells. And higher concentration of PS-MPs exposure could cause more severe damage of testicular structures (Fig. $2 \mathrm{E})$.

\section{Exposure to PS-MPs reduced the content of testosterone, LH and FSH in serum}

To explore the effects of PS-MPs exposure on the concentration of reproductive hormones, we detected the levels of testosterone, $\mathrm{LH}$ and FSH in serum. The results indicated that $\mathrm{LH}$ levels were decreased apparently in a dose-dependent manner after treatment with PS-MPs (Fig. 3A). As shown in Fig. 3B, the concentrations of FSH in serum exhibited an appreciable decrease in all treatment groups, and the decrease was most obvious in the $0.5 \mu \mathrm{m}$ PS-MPs treatment group. Meanwhile, the concentrations of testosterone in serum were markedly declined following exposure to various sizes of PS-MPs (Fig. 3C).

\section{PS-MPs downregulated the expression of steroidogenic enzymes and StAR in mice}

To assess whether PS-MPs may affect testosterone synthesis, we detected the levels of enzymes correlated with testosterone synthesis in the testis tissues. The results showed that the expression of P450scc, P450c17, 3ß-HSD, and 17 $\beta$-HSD was downregulated in the testis tissues (Fig. 4A and B). And for the same particle size of PS-MPs, the decrease was more obvious in the $1000 \mu \mathrm{g} / \mathrm{L}$ exposure group than in the $100 \mu \mathrm{g} / \mathrm{L}$ exposure group. In addition, we detected StAR in testes of PS-MPs-treated mice by western blotting (Fig. 4A and B) and immunofluorescence analyses (Fig. 4C), and StAR was decreased apparently in PS-MPs treated group compared with control group.

\section{Entering of PS-MPs into Leydig cells in vitro}

Confocal imaging results revealed that PS-MPs attached to and became internalized by Leydig cells (Fig. $5)$.

\section{PS-MPs inhibited the expression of testosterone, steroidogenic enzymes and StAR in primary Leydig cells}

Testosterone synthesis is related to steroid synthase in Leydig cells. We exposed Leydig cells to various concentrations of PS-MPs, and examined the concentrations of testosterone in the supernatant by Elisa. Figure $6 \mathrm{~A}$ showed that the contents of testosterone were declined following treatment with PS-MPs. RTqPCR consequences verified that the mRNA levels of the above enzymes were all decreased (Fig. 6B). Subsequently, we detected the levels of steroidogenic enzymes in Leydig cells. A concentration-dependent 
decreasing trend of P450scc, P450c17, 3 $\beta$-HSD, and 17 $\beta$-HSD were observed following exposure to PSMPs in Leydig cells (Fig. 6C and D). Meanwhile, the expression of StAR in Leydig cells was decreased remarkably with increasing PS-MPs concentrations (Fig. 6B, C and D).

\section{PS-MPs exposure inhibited the activation of AC/cAMP/PKA pathway in primary Leydig cells}

In order to explore the role of AC/CAMP/PKA pathway in the expression of StAR, we first observed that AC kinase activity was suppressed in PS-MPs-treated Leydig cells (Fig. 7A). And Elisa analysis revealed that the content of CAMP was declined following treatment with PS-MPs (Fig. 7B). Moreover, PKA kinase activity was dampened with the dose of PS-MPs-exposure (Fig. 7C), and PKA catalytic subunits (PRKACA and PRKACB) decreased with the concentration of PS-MPs-exposure (Fig. 7D and E). These results elucidated that AC/CAMP/PKA pathway was involved in the inhibition of StAR expression by PS-MPs. To prove this assumption, we used $20 \mathrm{mM}$ forskolin (cAMP agonist) and $0.1 \mathrm{mM}$ 8-bromo-cAMP (PKA agonist) to treat cells. The results indicated that the reduction of StAR levels caused by PS-MPs was alleviated after treated by forskolin (Fig. 7F and G) and 8-bromo-cAMP (Fig. 7H and I). Collectively, these results implied that PS-MPs decreased StAR expression by inhibiting activation of AC/CAMP/PKA pathway.

\section{Exposure to PS-MPs induced decrease of LHR level in primary Leydig cells}

In general, LH binds to LHR located on the membrane of Leydig cells, resulting in activation of AC/cAMP/PKA pathway. To explore the specific reason of AC/CAMP/PKA pathway inhibition induced by PS-MPs, we detected the expression of LHR in testes (Fig. 8A and B) and Leydig cells (Fig. 8C and D). Western blotting analysis revealed that PS-MPs induced a reduction of LHR level. RT-qPCR consequences showed that the mRNA level of LHR was decreased (Fig. 8E). Elisa results revealed that the transcriptional enhancer Sp1 was downregulated and the suppressor AP-2 was upregulated (Fig. 8F and $\mathrm{G)}$.

\section{Regulation of LHR affected the level of StAR, steroidogenic enzymes and testosterone in PS-MPs- exposed primary Leydig cells}

To determine the role of LHR on a decrease in testosterone levels induced by PS-MPs in Leydig cells, the cells were transfected with LHR by lentivirus. QRT-PCR and Western blotting analysis suggested that the level of LHR in the Leydig cells transfected with LHR by lentivirus was overexpressed (Fig. 9A and C). The levels of testosterone and enzymes involved in testosterone synthesis under basal condition or treatment with PS-MPs were checked in Leydig cells infected with LHR or Vector with lentivirus. As shown in Fig. 9B and Fig. 9C, the overexpression of LHR could alleviate the reduction of testosterone and enzymes levels induced by PS-MPs.

\section{Discussion}


In present study, we discovered that polystyrene MPs (PS-MPs) treatment induced the destruction of testicular histology, abnormal spermatogenesis, and interference of hormone secretion in serum. In those hormones, testosterone plays a crucial role in the process of spermatogenesis and male reproductive system, and its synthesis and secretion are mainly regulated via by LH-dependent signaling pathways in Leydig cells $[28,29]$. In this study, primary Leydig cells were used to discuss the mechanisms of the severely decreased testosterone levels that caused by PS-MPs treatment. Firstly, we confirmed that PSMPs treatment affected the expression levels of steroidogenic enzymes. StAR is an important regulator of steroid hormone synthesis. And we discovered that following exposure to PS-MPs, the expression of StAR was obviously suppressed. Many factors affected the expression of StAR, such as CAMP/PKA signaling pathway, protein kinase $C$, and regulatory factors $[32,33,34]$. However, CAMP/PKA signaling pathway was the main factor affecting the expression of StAR. In our results, the inhibition of cAMP/PKA signaling pathway was observed, and the decrease of StAR expression induced by PS-MPs was alleviated following treatment of CAMP agonist and PKA agonist. In general, the CAMP/PKA signaling pathway was activated when LH binds to LHR. Meanwhile, we found that PS-MPs triggered a decrease of LHR protein levels, and overexpression of LHR could alleviate the reduction of testosterone levels induced by PS-MPs. In conclusion, MPs reduced testosterone levels via regulating the testosterone synthesis pathway which was depended by LH, and the LHR was the critical initiator.

In this study, we had planned to try to explore the relationship between degrees of toxicity and particle size of MPs, so we chose three sizes $(0.5 \mu \mathrm{m}, 4 \mu \mathrm{m}, 10 \mu \mathrm{m})$ of MPs to conduct the animal experiments in vivo. Whereas, we could not find the significant difference among the three sizes in indexes related to reproductive ability. Well, these results were similar with some researches which regarded that PS-MPs of 0.5 and $50 \mu \mathrm{m}$ were no difference to induce gut microbiota dysbiosis [35]. In addition, our results revealed that PS-MPs attached to and became internalized by Leydig cells. The results were similar with previous study which demonstrated that environmentally exposed MPs particles were internalized significantly into macrophages [36]. The doses of PS-MPs used in vitro experiments were selected for the purpose of building a cell model of PS-MPs-induced testosterone-reduction for subsequent studies on the mechanism.

It is the first study to explore the reproductive effects of long-term MPs-exposure under the environmental pollution concentrations. In this study, the choice of MPs concentrations $(100 \mu \mathrm{g} / \mathrm{L}$ and $1000 \mu \mathrm{g} / \mathrm{L})$ based on both some previous studies and were close to those found in the natural contaminated areas $[15,19,35]$. We can find there were concentration-dependent decreases among the sperm abnormality in $4 \mu \mathrm{m}$ group, FSH level in $0.5 \mu \mathrm{m}$ group, and several steroidogenic enzymes levels in three sizes groups. The doses of PS-MPs used in vitro experiments were selected for the purpose of building a cell model of PS-MPs-induced testosterone-reduction for subsequent studies on the mechanism.

In this study, we firstly demonstrated that long-term exposure to PS-MPs in environmental pollution concentrations caused damage to testicular tissue structure, decreased sperm quality and decreased testosterone levels, resulting in male reproductive toxicity in mice. In addition, we showed that the decrease of testosterone level induced by PS-MPs was achieved by inhibiting the LH-mediated 
LHR/CAMP/PKA/StAR pathway. Moreover, LHR may play a critical role in decrease of testosterone level induced by PS-MPs.

\section{Conclusions}

Taken together, destruction of testicular histology, abnormal spermatogenesis, and interference of hormone secretion in serum were observed in mice following 180-days-exposure to $0.5 \mu \mathrm{m}, 4 \mu \mathrm{m}$, and 10 $\mu \mathrm{m}$ PS-MPs in environmental pollution concentrations. PS-MPs induced a reduction of testosterone levels through downregulation of LH-mediated LHR/CAMP/PKA/StAR pathway. Our findings may provide new perspectives for understanding the reproductive toxicity of PS-MPs in mammals.

\section{Materials And Methods}

\section{Test Materials}

Fluorescent polystyrene microplastics (PS-MPs) $(10 \mathrm{mg} / \mathrm{mL})$ with different sizes $(0.5 \mu \mathrm{m}, 4 \mu \mathrm{m}, 10 \mu \mathrm{m})$ were purchased from Tianjin Baseline ChromTech Research Centre (Tianjin,

China). Fetal bovine serum (FBS) and Dulbecco's modified Eagle's medium (DMEM)-F12 were obtained from Gibco (Grand Island, NY). Penicillin-streptomycin were gained from Sigma-Aldrich (St.Louis, MO).

\section{Animals and Treatment}

Specifc pathogen-free (SPF) male BALB/c mice aged six-weeks were obtained from Medical School of Yangzhou University (Yangzhou, China). Mice were divided into 7 groups with 15 mice in each group. Mice in each group were randomly placed in three cages $(n=5 /$ cage). Mice of PS-MPs exposure group were given drinking water containing $100 \mu \mathrm{g} / \mathrm{L}$ and $1000 \mu \mathrm{g} / \mathrm{L}$ PS-MPs with sizes of $0.5 \mu \mathrm{m}, 4 \mu \mathrm{m}$, and 10 $\mu \mathrm{m}$ for 180 continuous days. For control group, mice were provided the blank water without PS-MPs. After the exposure period, mice were anesthetized to gain blood and testes. All experimental protocols were approved by the Animal Care and Use Committee of Nanjing University according to the animal protocol number SYXK (Su) 2009-0017.

\section{Cell Culture and PS-MPs Exposure}

Primary Leydig cells were isolated from 3-week-old BALB/c male mouse testes, as described previously (27884405). Cells were cultured in DMEM-F12 supplemented with $10 \% \mathrm{FBS}, 1 \%$ penicillin-streptomycin, and $0.1 \%$ human chorionic gonadotropin ( $\mathrm{hCG}$ ). After adherence for $48 \mathrm{~h}$, cells were cultured in DMEMF12 containing various concentrations of PS-MPs with a diameter of $0.5 \mu \mathrm{m}$ for $24 \mathrm{~h}$. The concentration of PS-MPs was diluted to $0.1,0.15,0.2 \mathrm{mg} / \mathrm{mL}$.

\section{Agonist Treatment}


Cells were cultured in DMEM-F12 supplemented with 10\% FBS for $96 \mathrm{~h}$, and then cultured in serum-free medium in the presence of $0.1 \%$ hCG and $0.2 \mathrm{mg} / \mathrm{mL}$ PS-MPs for $1 \mathrm{~h}$. Subsequently, $20 \mathrm{mM}$ forskolin (MedChemExpress, Monmouth Junction, USA) or $0.1 \mathrm{mM}$ 8-bromo-cAMP (MedChemExpress, Monmouth Junction, USA) were added in medium for $24 \mathrm{~h}$.

\section{Sperm Viability and Sperm Abnormality Assessment}

Sperm viability and sperm abnormality assessment were performed as previously described [37].

\section{H\&E Staining}

H\&E staining was carried out as previously described [37].

\section{Quantitative Real-time PCR (qRT-PCR)}

Total RNA was extracted using Trizol reagent (Vazyme, Nanjing, China) according to the manufacturer's protocol. The cDNA was synthesized by using HiScript Q RT SuperMix (Vazyme, Nanjing, China). QRTPCR were performed as previously described [38]. The primer sequences were exhibited in Supplementary Table S1.

\section{Western Blotting and ELISA}

Proteins were purified from testis tissues or Leydig cells by using the RIPA buffer (Beyotime, Shanghai, China). Western blotting was carried out as previously mentioned [38]. Proteins were separated using $12 \%$ SDS-polyacrylamide gel electrophoresis and electrophoretically transferred to polyvinylidene fluoride (PVDF) membranes. Transferred blots were incubated with rabbit anti-CYP11A (P450scc) (Proteintech Group, Rosemont, IL, USA) , rabbit anti-CYP17A (P450c17) (Proteintech Group, Rosemont, IL, USA), rabbit anti-StAR (Cell Signaling Technology, USA), mouse anti-HSD3 $\beta$ (Proteintech Group, Rosemont, IL, USA), rabbit anti-HSD17 2 (Proteintech Group, Rosemont, IL, USA), rabbit anti-LHR (Proteintech Group, Rosemont, IL, USA), mouse anti-GAPDH (Proteintech Group, Rosemont, IL, USA) overnight at $4^{\circ} \mathrm{C}$. The specific information of antibodies was shown in Supplementary Table S2. The secondary antibody horseradish peroxidase-conjugated goat anti-rabbit/mouse IgG (Boster, Wuhan, China) was used in present study. In addition, the levels of testosterone, LH and FSH in serum were measured with ELISA kits (Elabscience Biotechnology Co., Ltd) according to manufacturer's instructions.

\section{Immunofluorescence Staining}

Immunofluorescence staining were performed as previously described [38]. The primary antibody rabbit anti-StAR (Cell Signaling Technology, USA) was employed. The secondary antibody Alexa Fluor 594conjugated goat anti-rabbit IgG was used in the study. Nuclei were stained with DAPI (Sigma). The images were captured using FV10i microscope (Olympus, Japan).

\section{Statistical Analysis}


GraphPad Prism 8 (USA) was applied for statistical analysis. Oneway ANOVA with Dunnett's t-test was used to analyze differences between groups. The data were shown as mean values \pm SD. The value $P<$ 0.05 was regarded as statistically significant.

\section{Declarations}

\section{Ethics approval and consent to participate}

All experimental procedures were approved by the animal protocol number SYXK (Su) 2009-0017 by the Animal Care and Use Committee of Nanjing University.

\section{Consent for publication}

Not applicable.

\section{Availability of data and materials}

The datasets supporting the conclusions of this article are included within the article, Supplementary Materials, and cell imaging.

\section{Competing interests}

The authors declare no competing financial interests.

\section{Funding}

This work was supported by the Natural Science Foundation of Jiangsu Province of China (BK20190316), Fundamental Research Funds for the Central Universities (0214-14380438, 021414380471) and National Natural Science Foundation of China (31870492, 31901182 and 31971517).

\section{Authors' contributions}

Haibo Jin: Investigation, Data curation, Writing-Original Draft. Minghao Yan, Chun Pan, Zhenyu Liu, and Xiaoxuan Sha: Writing-Review and Editing. Chengyue Jiang, Luxi Li, and Mengge Pan: Data interpretation. Dongmei Li, Xiaodong Han and Jie Ding: Supervision, Resources, Writing-Review \& Editing, Project administration, Funding acquisition.

\section{Acknowledgements}

We gratefully thank Xiannan Meng, Ling Zhang, Tan Ma, Yuan Zhou, Jinling Zhu, Changliang Zhang, and Qiancheng Shi (Nanjing University) for sampling collection in mice.

\section{Authors' information}


1 Immunology and Reproductive Biology Laboratory \& State Key Laboratory of Analytical Chemistry for Life Science, Medical School, Nanjing University, Hankou Road 22, Nanjing, Jiangsu 210093, China;

2 Jiangsu Key Laboratory of Molecular Medicine, Nanjing University, Nanjing 210093, China;

* Corresponding author at: Immunology and Reproduction Biology Laboratory \& State Key Laboratory of Analytical Chemistry for Life Science, Medical School, Nanjing University, Nanjing, Jiangsu 210093, China.

\section{References}

1. Moore CJ. Synthetic polymers in the marine environment: a rapidly increasing, long-term threat. Environ Res. 2008;108 2:131-9; doi:10.1016/j.envres.2008.07.025. https://www.ncbi.nlm.nih.gov/pubmed/18949831.

2. Rochman CM, Browne MA, Halpern BS, Hentschel BT, Hoh E, Karapanagioti HK, et al. Policy: Classify plastic waste as hazardous. Nature. 2013;494 7436:169 - 71; doi: 10.1038/494169a. https://www.ncbi.nlm.nih.gov/pubmed/23407523.

3. Cozar A, Echevarria F, Gonzalez-Gordillo JI, Irigoien X, Ubeda B, Hernandez-Leon S, et al. Plastic debris in the open ocean. Proc Natl Acad Sci U S A 2014;111 28:10239-44; doi:10.1073/pnas.1314705111. https://www.ncbi.nlm.nih.gov/pubmed/24982135.

4. Andrady AL. Microplastics in the marine environment. Mar Pollut Bull. 2011;62 8:1596-605; doi:10.1016/j.marpolbul.2011.05.030. https://www.ncbi.nlm.nih.gov/pubmed/21742351.

5. Thompson RC, Olsen Y, Mitchell RP, Davis A, Rowland SJ, John AW, et al. Lost at sea: where is all the plastic? Science. 2004;304 5672:838; doi: 10.1126/science.1094559. https://www.ncbi.nlm.nih.gov/pubmed/15131299.

6. Barnes DK, Galgani F, Thompson RC, Barlaz M. Accumulation and fragmentation of plastic debris in global environments. Philos Trans R Soc Lond B Biol Sci. 2009;364 1526:1985-98; doi:10.1098/rstb.2008.0205. https://www.ncbi.nlm.nih.gov/pubmed/19528051.

7. Steer M, Cole M, Thompson RC, Lindeque PK. Microplastic ingestion in fish larvae in the western English Channel. Environ Pollut. 2017;226:250-9; doi:10.1016/j.envpol.2017.03.062. https://www.ncbi.nlm.nih.gov/pubmed/28408185.

8. Wagner M, Scherer C, Alvarez-Munoz D, Brennholt N, Bourrain X, Buchinger S, et al. Microplastics in freshwater ecosystems: what we know and what we need to know. Environ Sci Eur 2014;26 1:12; doi:10.1186/s12302-014-0012-7. https://www.ncbi.nlm.nih.gov/pubmed/28936382.

9. Sadri SS, Thompson RC. On the quantity and composition of floating plastic debris entering and leaving the Tamar Estuary, Southwest England. Mar Pollut Bull. 2014;81 1:55-60; doi:10.1016/j.marpolbul.2014.02.020. https://www.ncbi.nlm.nih.gov/pubmed/24613232.

10. Miranda DA, de Carvalho-Souza GF. Are we eating plastic-ingesting fish? Mar Pollut Bull. 2016;103 1-2:109 - 14; doi: 10.1016/j.marpolbul.2015.12.035. https://www.ncbi.nlm.nih.gov/pubmed/26763323. 
11. Setala O, Fleming-Lehtinen $\mathrm{V}$, Lehtiniemi M. Ingestion and transfer of microplastics in the planktonic food web. Environ Pollut 2014;185:77-83; doi:10.1016/j.envpol.2013.10.013. https://www.ncbi.nlm.nih.gov/pubmed/24220023.

12. Yang YF, Chen CY, Lu TH, Liao CM. Toxicity-based toxicokinetic/toxicodynamic assessment for bioaccumulation of polystyrene microplastics in mice. J Hazard Mater. 2019;366:703-13; doi:10.1016/j.jhazmat.2018.12.048. https://www.ncbi.nlm.nih.gov/pubmed/30583240.

13. Dong CD, Chen CW, Chen YC, Chen HH, Lee JS, Lin CH. Polystyrene microplastic particles: In vitro pulmonary toxicity assessment. J Hazard Mater 2020;385:121575; doi:10.1016/j.jhazmat.2019.121575. https://www.ncbi.nlm.nih.gov/pubmed/31727530.

14. Umamaheswari S, Priyadarshinee S, Bhattacharjee M, Kadirvelu K, Ramesh M. Exposure to polystyrene microplastics induced gene modulated biological responses in zebrafish (Danio rerio). Chemosphere. 2020:128592; doi: 10.1016/j.chemosphere.2020.128592. https://www.ncbi.nlm.nih.gov/pubmed/33077188.

15. Lu Y, Zhang Y, Deng Y, Jiang W, Zhao Y, Geng J, et al. Uptake and Accumulation of Polystyrene Microplastics in Zebrafish (Danio rerio) and Toxic Effects in Liver. Environ Sci Technol. 2016;50 7:4054-60; doi:10.1021/acs.est.6b00183. https://www.ncbi.nlm.nih.gov/pubmed/26950772.

16. Deng $Y$, Zhang $Y$, Lemos $B$, Ren $H$. Tissue accumulation of microplastics in mice and biomarker responses suggest widespread health risks of exposure. Sci Rep. 2017;7:46687; doi:10.1038/srep46687. https://www.ncbi.nlm.nih.gov/pubmed/28436478.

17. Ding J, Zhang S, Razanajatovo RM, Zou H, Zhu W. Accumulation, tissue distribution, and biochemical effects of polystyrene microplastics in the freshwater fish red tilapia (Oreochromis niloticus). Environ Pollut. 2018;238:1-9; doi:10.1016/j.envpol.2018.03.001. https://www.ncbi.nlm.nih.gov/pubmed/29529477.

18. Zheng H, Wang J, Wei $X$, Chang L, Liu S. Proinflammatory properties and lipid disturbance of polystyrene microplastics in the livers of mice with acute colitis. Sci Total Environ. 2021;750:143085; doi:10.1016/j.scitotenv.2020.143085. https://www.ncbi.nlm.nih.gov/pubmed/33182181.

19. Jin Y, Lu L, Tu W, Luo T, Fu Z. Impacts of polystyrene microplastic on the gut barrier, microbiota and metabolism of mice. Sci Total Environ. 2019;649:308-17; doi:10.1016/j.scitotenv.2018.08.353. https://www.ncbi.nlm.nih.gov/pubmed/30176444.

20. Barboza LGA, Vieira LR, Branco V, Figueiredo N, Carvalho F, Carvalho C, et al. Microplastics cause neurotoxicity, oxidative damage and energy-related changes and interact with the bioaccumulation of mercury in the European seabass, Dicentrarchus labrax (Linnaeus, 1758). Aquat Toxicol. 2018;195:49-57; doi:10.1016/j.aquatox.2017.12.008. https://www.ncbi.nlm.nih.gov/pubmed/29287173.

21. Murphy F, Quinn B. The effects of microplastic on freshwater Hydra attenuata feeding, morphology \& reproduction. Environ Pollut. 2018;234:487-94; doi:10.1016/j.envpol.2017.11.029. https://www.ncbi.nlm.nih.gov/pubmed/29216486. 
22. Assas M, Qiu X, Chen K, Ogawa H, Xu H, Shimasaki Y, et al. Bioaccumulation and reproductive effects of fluorescent microplastics in medaka fish. Mar Pollut Bull. 2020;158:111446; doi:10.1016/j.marpolbul.2020.111446. https://www.ncbi.nlm.nih.gov/pubmed/32753222.

23. Sussarellu R, Suquet $M$, Thomas $Y$, Lambert $C$, Fabioux $C$, Pernet ME, et al. Oyster reproduction is affected by exposure to polystyrene microplastics. Proc Natl Acad Sci U S A 2016;113 9:2430-5; doi:10.1073/pnas.1519019113. https://www.ncbi.nlm.nih.gov/pubmed/26831072.

24. Hou B, Wang F, Liu T, Wang Z. Reproductive toxicity of polystyrene microplastics: In vivo experimental study on testicular toxicity in mice. J Hazard Mater 2021;405:124028; doi:10.1016/j.jhazmat.2020.124028. https://www.ncbi.nlm.nih.gov/pubmed/33087287.

25. Xie X, Deng T, Duan J, Xie J, Yuan J, Chen M. Exposure to polystyrene microplastics causes reproductive toxicity through oxidative stress and activation of the p38 MAPK signaling pathway. Ecotoxicol Environ Saf 2020;190:110133; doi:10.1016/j.ecoenv.2019.110133. https://www.ncbi.nlm.nih.gov/pubmed/31896473.

26. Amereh F, Babaei M, Eslami A, Fazelipour S, Rafiee M. The emerging risk of exposure to nano(micro)plastics on endocrine disturbance and reproductive toxicity: From a hypothetical scenario to a global public health challenge. Environ Pollut. 2020;261:114158; doi:10.1016/j.envpol.2020.114158. https://www.ncbi.nlm.nih.gov/pubmed/32088433.

27. Smith LB, Walker WH. The regulation of spermatogenesis by androgens. Semin Cell Dev Biol 2014;30:2-13; doi:10.1016/j.semcdb.2014.02.012. https://www.ncbi.nlm.nih.gov/pubmed/24598768.

28. Dufau ML. Endocrine regulation and communicating functions of the Leydig cell. Annu Rev Physiol. 1988;50:483-508; doi:10.1146/annurev.ph.50.030188.002411.

http://www.ncbi.nlm.nih.gov/pubmed/3288102.

29. Tremblay JJ. Molecular regulation of steroidogenesis in endocrine Leydig cells. Steroids. 2015;103:3-10; doi:10.1016/j.steroids.2015.08.001. https://www.ncbi.nlm.nih.gov/pubmed/26254606.

30. Jeong CB, Won EJ, Kang HM, Lee MC, Hwang DS, Hwang UK, et al. Microplastic Size-Dependent Toxicity, Oxidative Stress Induction, and p-JNK and p-p38 Activation in the Monogonont Rotifer (Brachionus koreanus). Environ Sci Technol. 2016;50 16:8849-57; doi:10.1021/acs.est.6b01441. https://www.ncbi.nlm.nih.gov/pubmed/27438693.

31. Yu P, Liu Z, Wu D, Chen M, Lv W, Zhao Y. Accumulation of polystyrene microplastics in juvenile Eriocheir sinensis and oxidative stress effects in the liver. Aquat Toxicol 2018;200:28-36; doi:10.1016/j.aquatox.2018.04.015. https://www.ncbi.nlm.nih.gov/pubmed/29709883.

32. Manna PR, Dyson MT, Eubank DW, Clark BJ, Lalli E, Sassone-Corsi P, et al. Regulation of steroidogenesis and the steroidogenic acute regulatory protein by a member of the CAMP responseelement binding protein family. Molecular endocrinology. 2002;16 1:184-99; doi:10.1210/mend.16.1.0759. http://www.ncbi.nlm.nih.gov/pubmed/11773448. 
33. Nishimura R, Shibaya M, Skarzynski DJ, Okuda K. Progesterone stimulation by LH involves the phospholipase-C pathway in bovine luteal cells. J Reprod Dev. 2004;50 2:257 - 61; doi:10.1262/jrd.50.257. http://www.ncbi.nlm.nih.gov/pubmed/15118253.

34. Liu MY, Lai HY, Yang BC, Tsai ML, Yang HY, Huang BM. The inhibitory effects of lead on steroidogenesis in MA-10 mouse Leydig tumor cells. Life sciences. 2001;68 8:849 - 59; doi: 10.1016/s0024-3205(00)00983-8. http://www.ncbi.nlm.nih.gov/pubmed/11213355.

35. Lu L, Wan Z, Luo T, Fu Z, Jin Y. Polystyrene microplastics induce gut microbiota dysbiosis and hepatic lipid metabolism disorder in mice. The Science of the total environment. 2018;631-632:449 - 58; doi: 10.1016/j.scitotenv.2018.03.051. http://www.ncbi.nlm.nih.gov/pubmed/29529433.

36. Ramsperger A, Narayana VKB, Gross W, Mohanraj J, Thelakkat M, Greiner A, et al. Environmental exposure enhances the internalization of microplastic particles into cells. Sci Adv. 2020;6 50; doi: 10.1126/sciadv.abd1211. https://www.ncbi.nlm.nih.gov/pubmed/33298447.

37. Jin H, Ma T, Sha X, Liu Z, Zhou Y, Meng X, et al. Polystyrene microplastics induced male reproductive toxicity in mice. J Hazard Mater. 2021;401:123430; doi:10.1016/j.jhazmat.2020.123430. https://www.ncbi.nlm.nih.gov/pubmed/32659591.

38. Ding J, Wang J, Jin H, Xia T, Cheng Y, Wu J, et al. Microcystin-LR reduces the synthesis of gonadotropin-releasing hormone by activating multiple signaling pathways resulting in decrease of testosterone in mice. Sci Total Environ. 2018;643:496-506; doi:10.1016/j.scitotenv.2018.06.123. https://www.ncbi.nlm.nih.gov/pubmed/29945085.

\section{Figures}


A

$0.5 \mu \mathrm{m}$
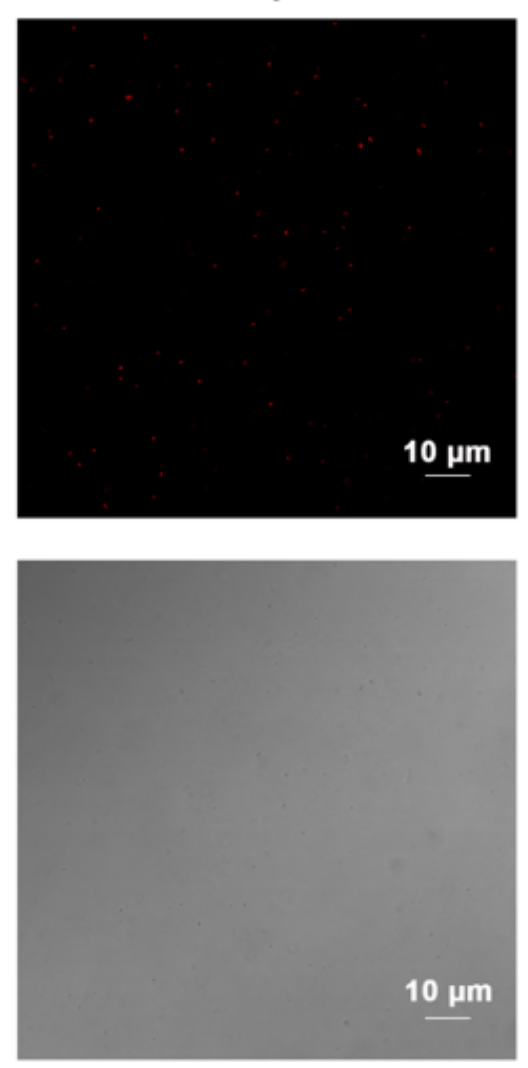

B

$0.5 \mu \mathrm{m}$

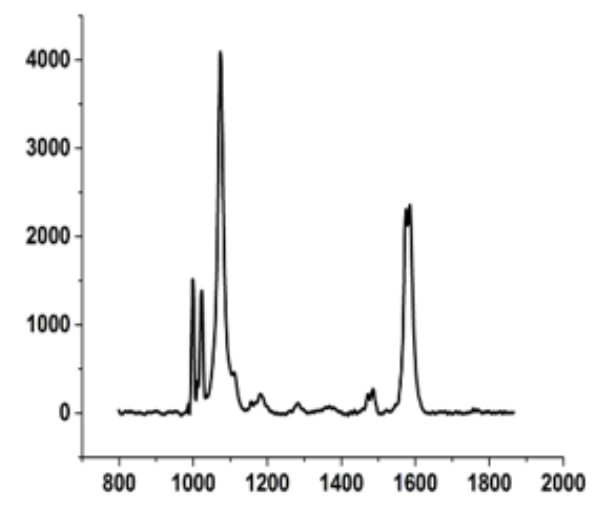

$4 \mu \mathrm{m}$
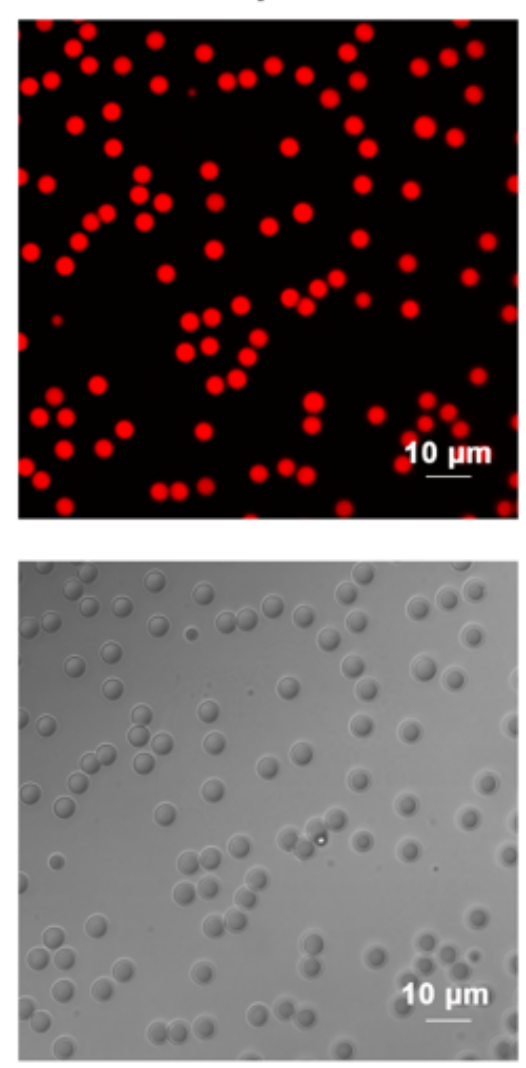

$4 \mu \mathrm{m}$

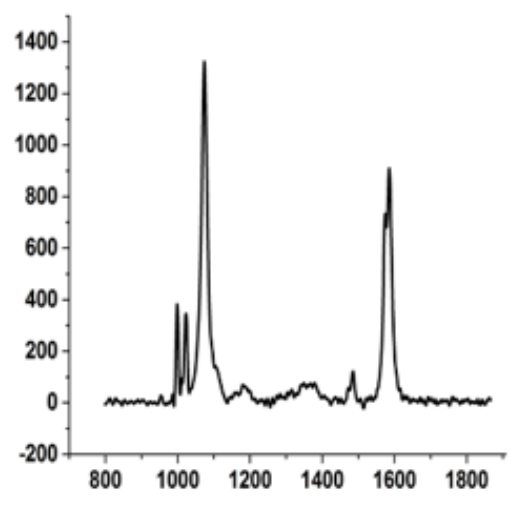

$10 \mu \mathrm{m}$
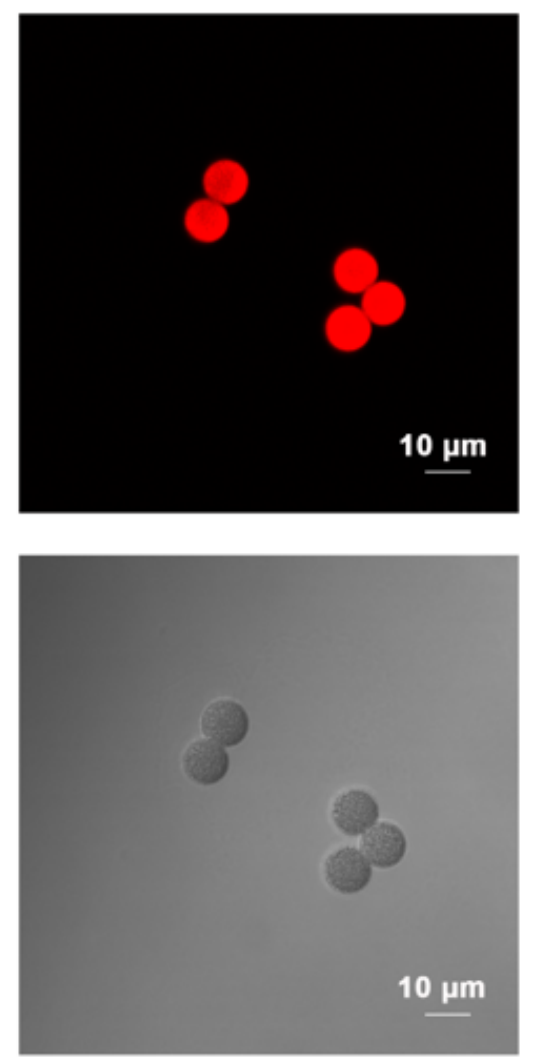

$10 \mu \mathrm{m}$

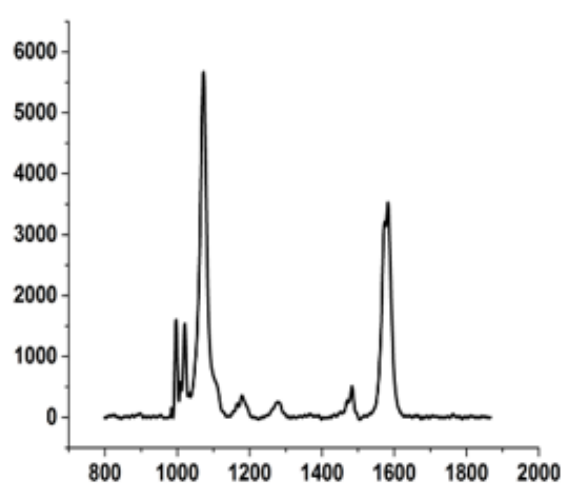

\section{Figure 1}

Characterization of polystyrene microplastics (PS-MPs). (A) Morphological detection of PS-MPs. Confocal imaging showing various sizes of PS-MPs. (B) Raman spectrum characterizations of PS-MPs. 
A

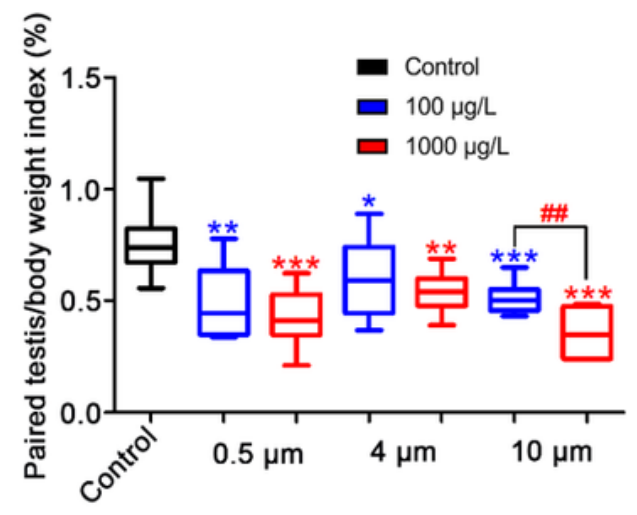

C

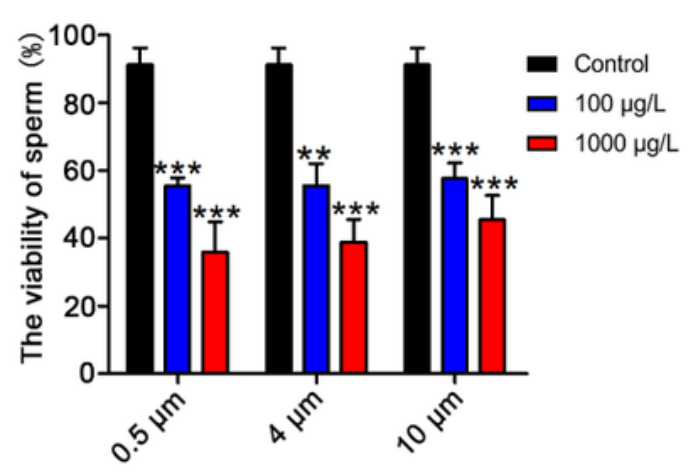

B

D
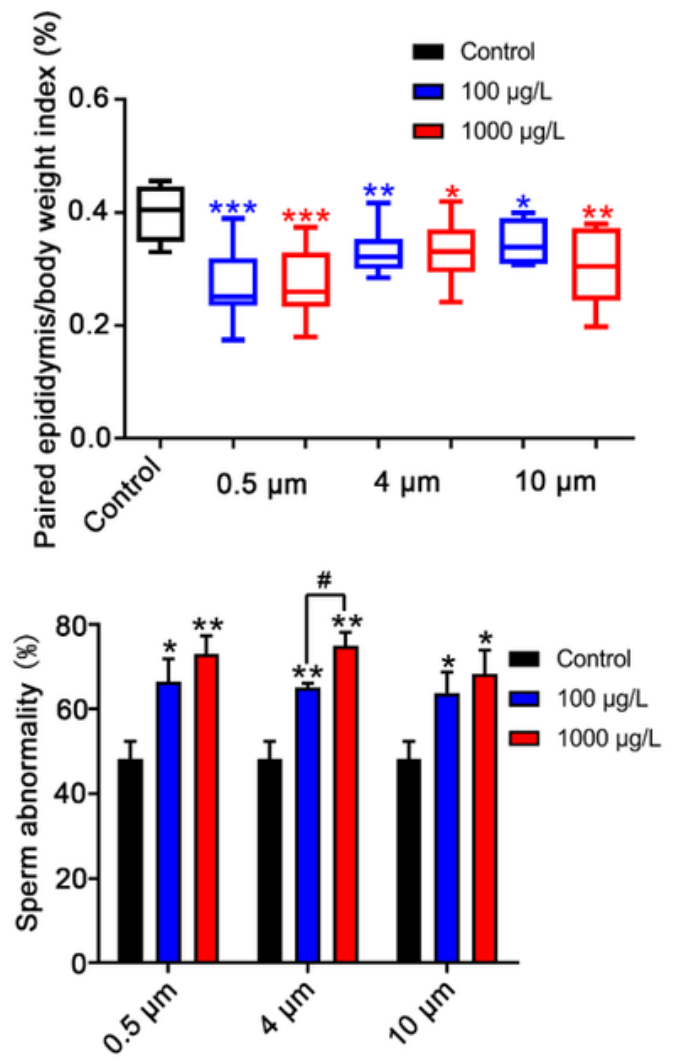

E

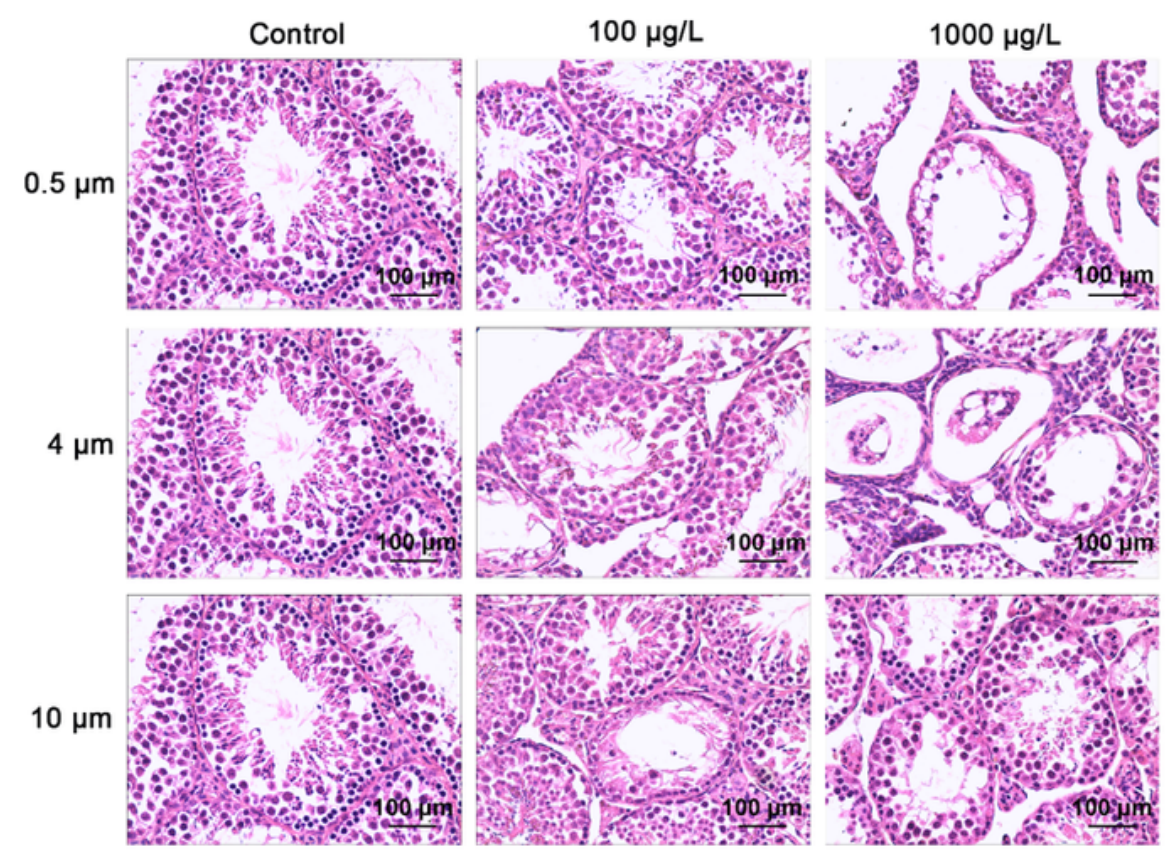

Figure 2

PS-MPs exposure induced reproductive toxicity in male mice. Mice were given drinking water containing different sizes of PS-MPs at $100 \mu \mathrm{g} / \mathrm{L}$ and $1000 \mu \mathrm{g} / \mathrm{L}$ for 180 continuous days. (A) The paired testis/body weight index were assessed $(n=15)$. (B) The paired epididymis/body weight index were analyzed $(n=15)$. (C) The viability of sperm was detected $(n=15)$. (D) The rate of sperm abnormality was calculated $(n=15)$. (E) Impact of PS-MPs on the testis structures was examined by H\&E staining. 


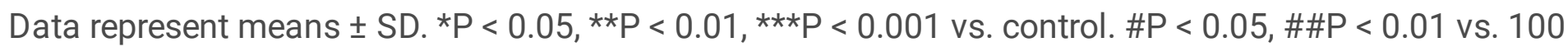
$\mu g / L$ group.

A

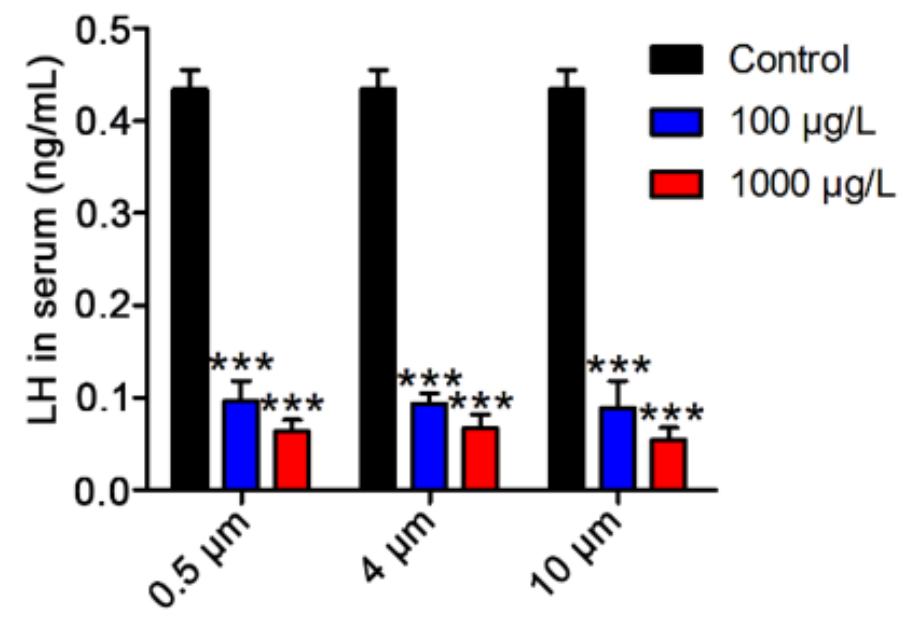

C

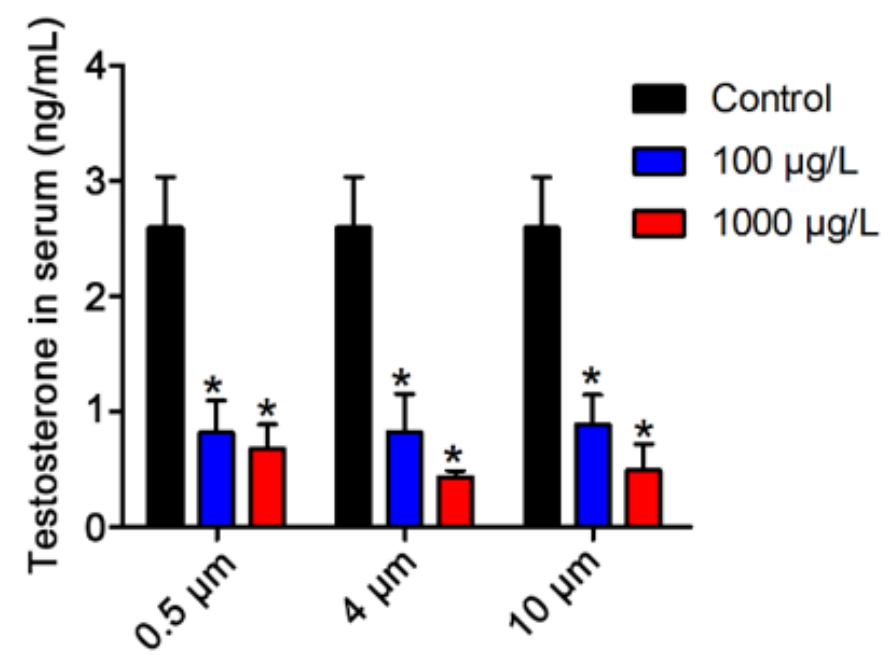

B

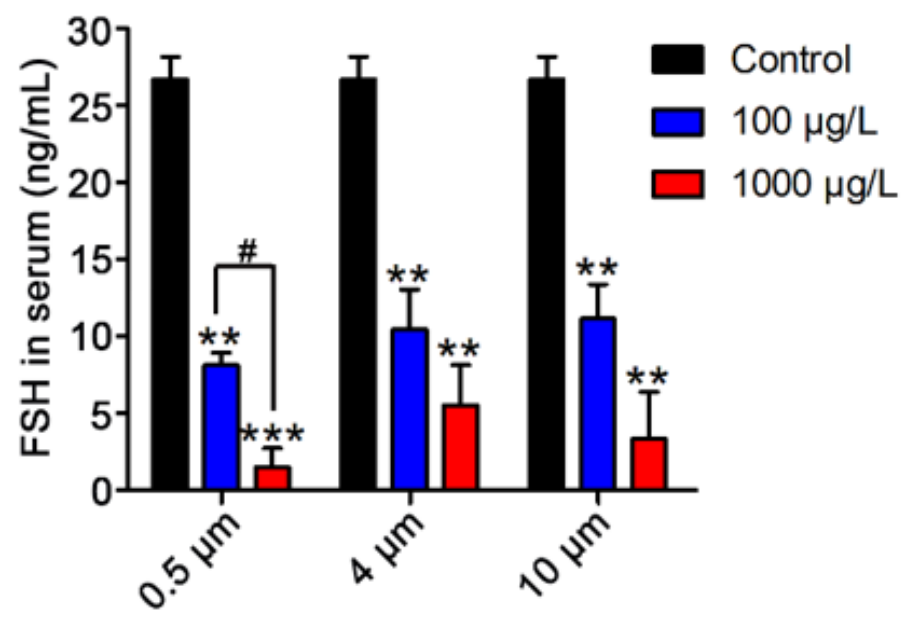

Figure 3

PS-MPs exposure decreased the content of testosterone, LH, FSH in serum. The content of LH (A), FSH $(B)$, and testosterone (C) in serum was measured by ELISA. Results are expressed as means \pm SD. $* P<$ $0.05, * * P<0.01, * * * P<0.001$ vs. control. \#P<0.05 vs. $100 \mu \mathrm{g} / \mathrm{L}$ group. 


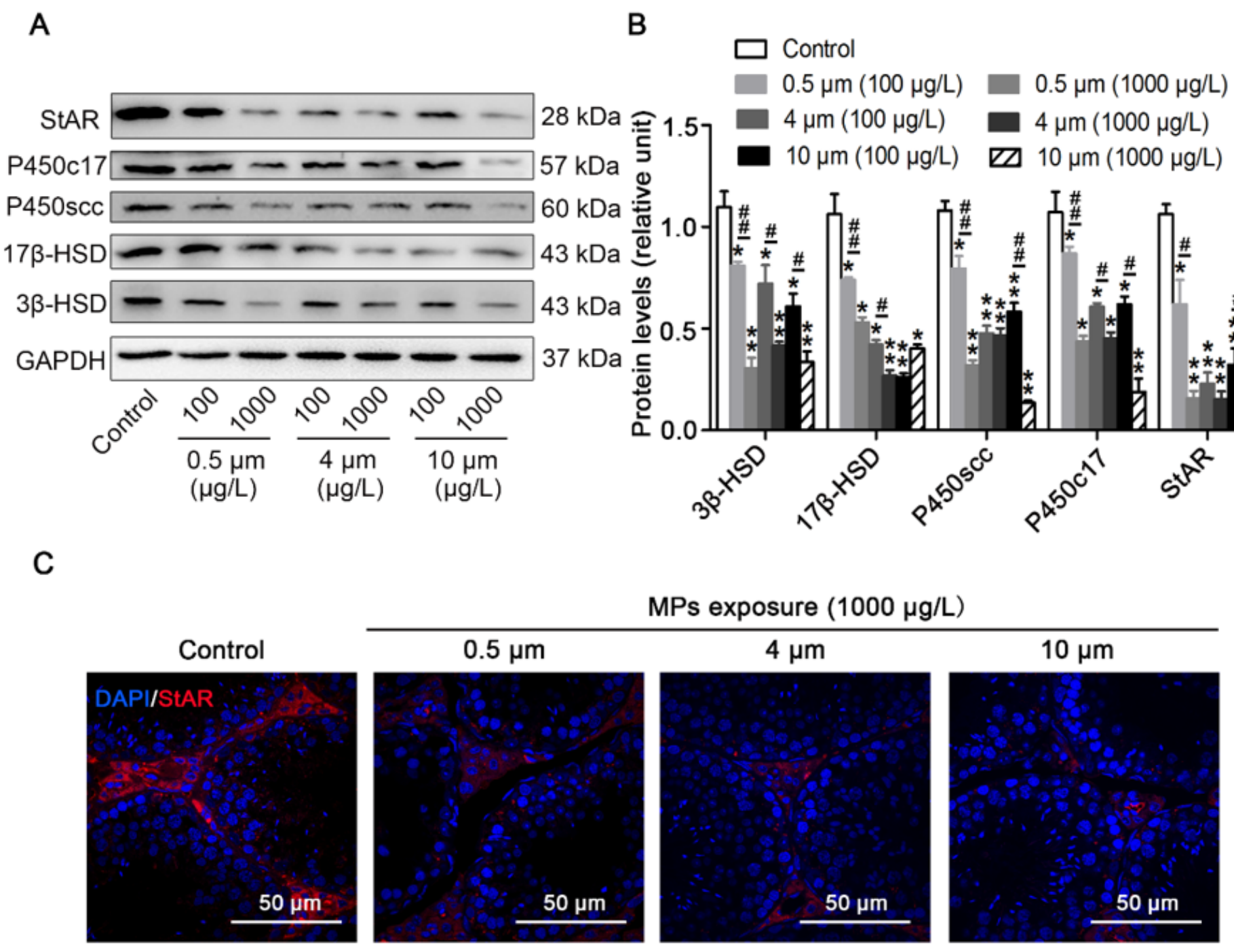

Figure 4

PS-MPs treatment downregulated the expression of steroidogenic enzymes and StAR in testes. Mice were given drinking water comprising PS-MPs with various sizes for 180 sustained days. (A, B) The expression

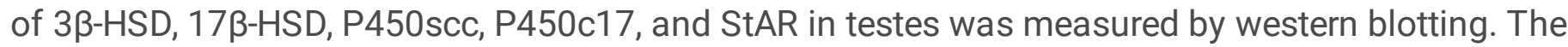
expression levels were quantified with ImageJ $(n=3)$. Data are expressed as means $\pm S D$. ${ }^{*} P<0.05, * * P<$ 0.01 vs. control. \#P < 0.05, \#\#P < 0.01 vs. $100 \mu \mathrm{g} / \mathrm{L}$ group. (C) The expression levels of StAR in mouse testicular tissues were tested by immunofluorescence staining. Testicular tissues were stained with StAR (red) and DAPI (blue) (scale bar $=50 \mu \mathrm{m}, \mathrm{n}=3$ ). 
A

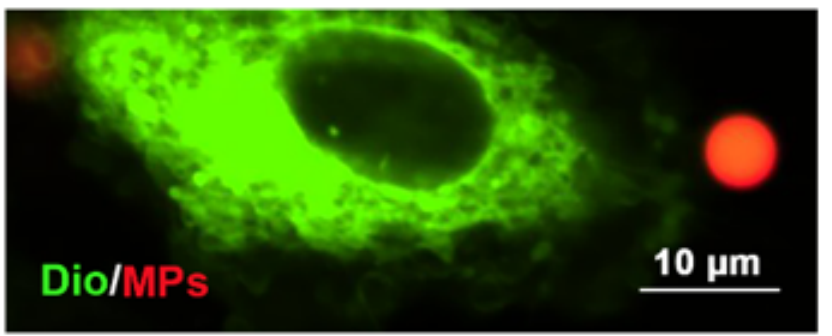

C

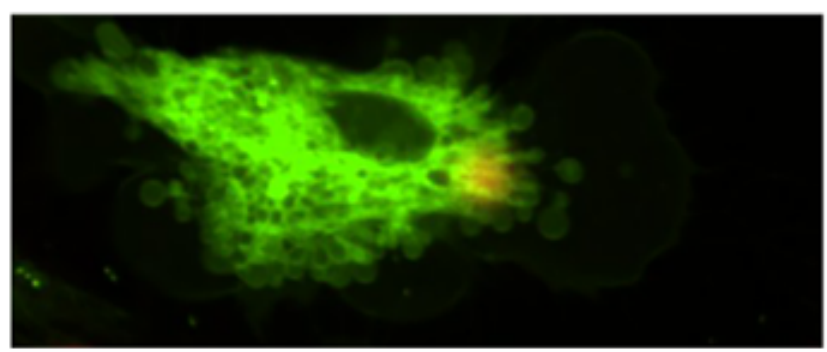

$\mathbf{E}$

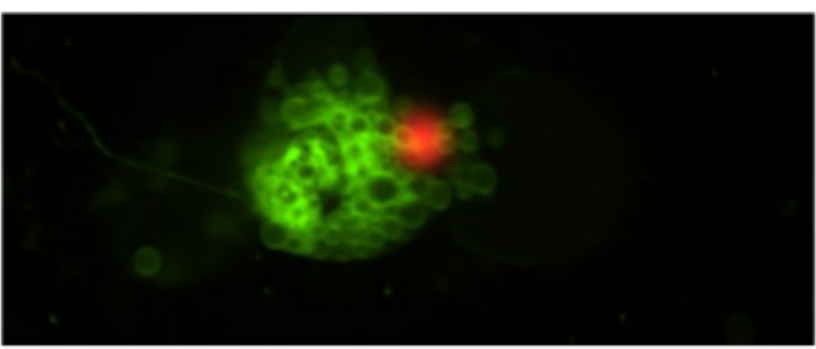

B

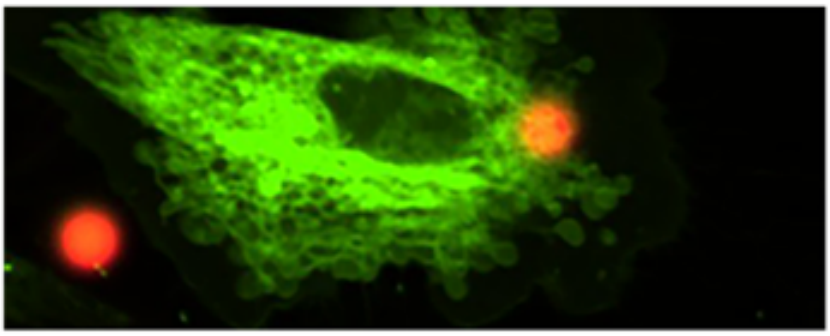

D

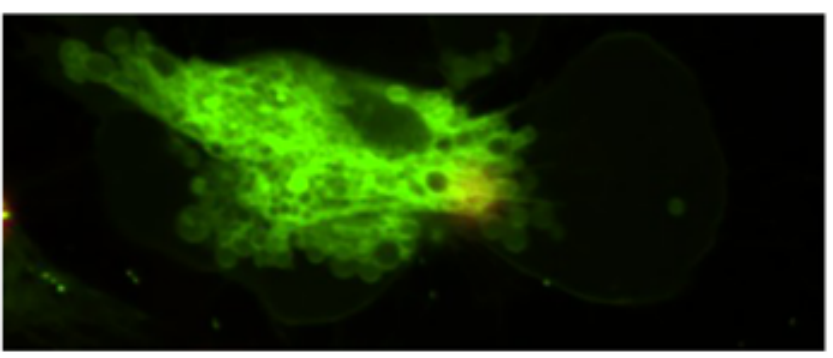

$\mathbf{F}$

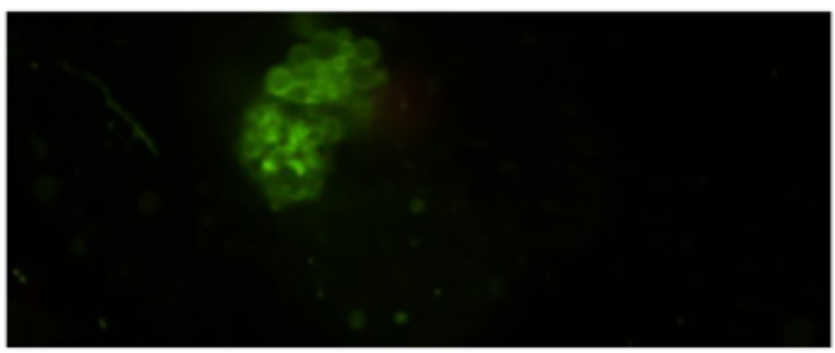

Figure 5

Images of particle-cell interactions of PS-MPs. Leydig cells were exposed to PS-MPs for $24 \mathrm{~h}$. Spinning disc confocal images of the cells with fluorescently labeled filamentous actin (green), PS-MPs (red) (scale $\operatorname{bar}=10 \mu \mathrm{m})$. 
A

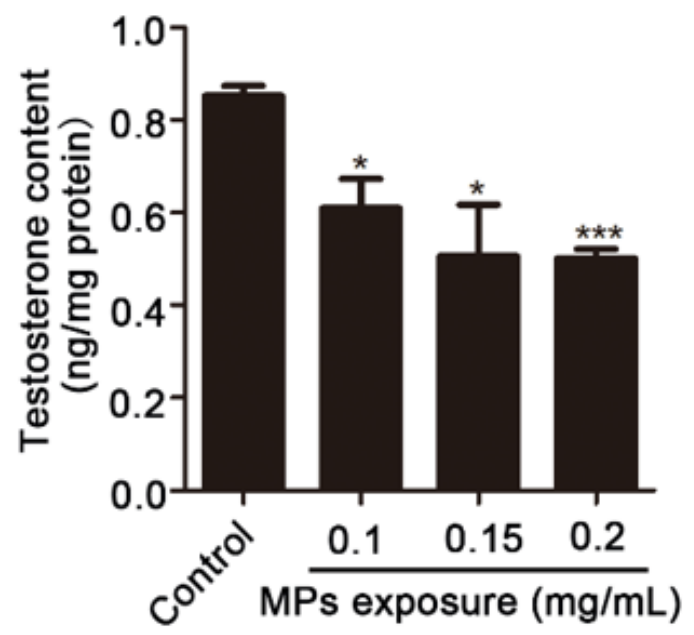

B

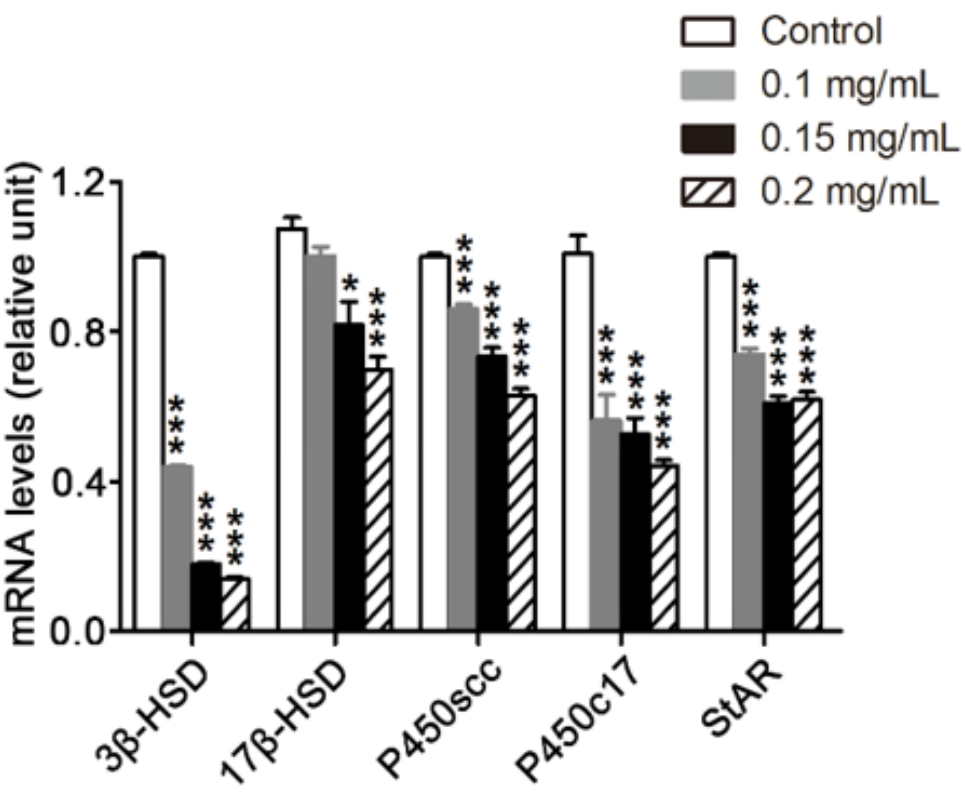

C

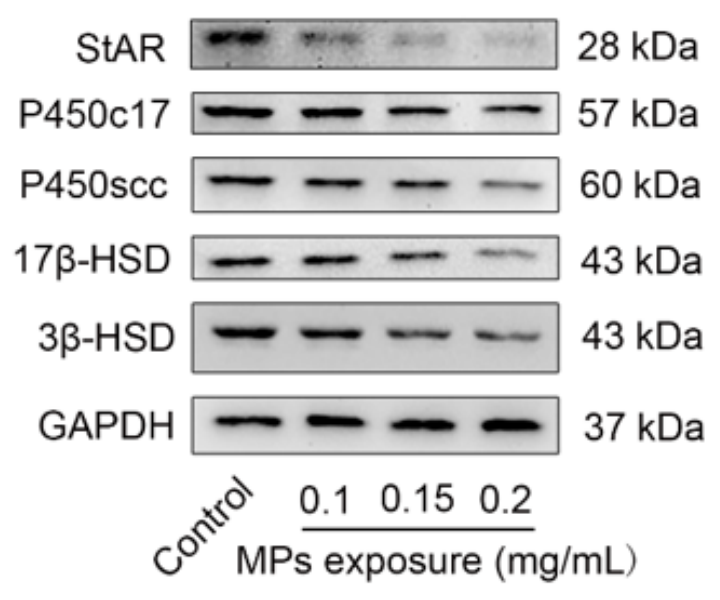

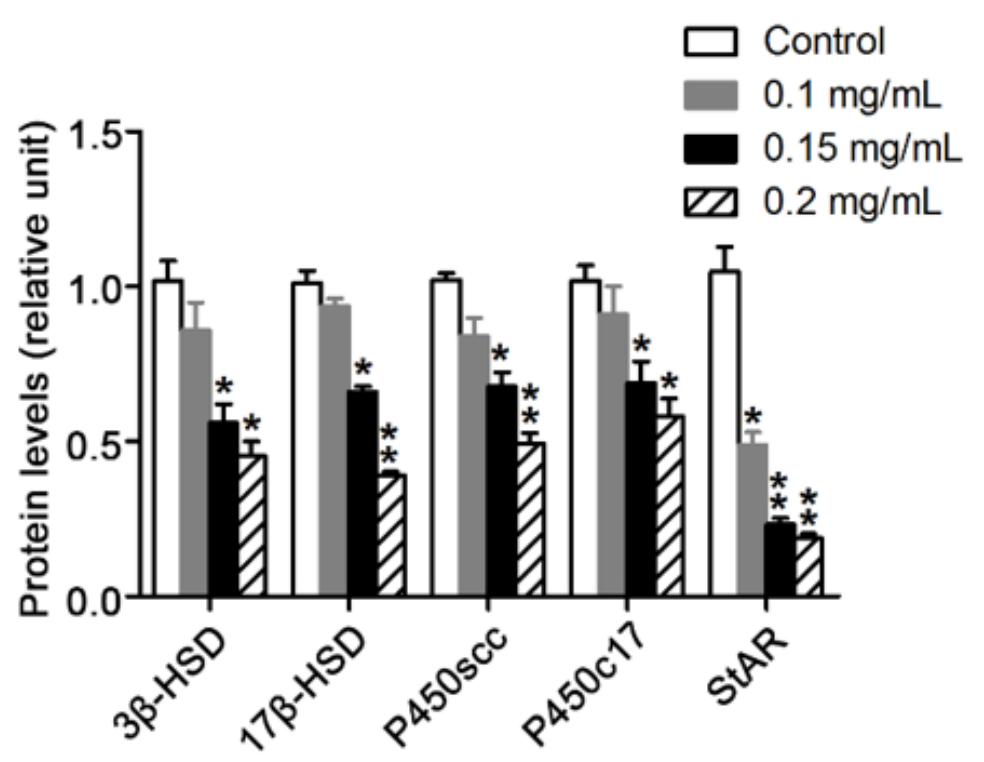

Figure 6

Expression of steroidogenic enzymes and StAR decreased in Leydig cells after PS-MPs treatment.

Primary Leydig cells were exposed to $0.5 \mu \mathrm{m}$ PS-MPs for $24 \mathrm{~h}$ at various concentrations as indicated. (A) The content of testosterone in supernatant was determined by ELISA assays $(n=3)$. (B) The mRNA expression levels of $3 \beta-H S D, 17 \beta-H S D, P 450 s c c, P 450 c 17$, and StAR in Leydig cells after treatment with

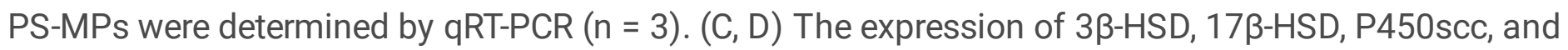
$\mathrm{P} 450 \mathrm{c} 17$ in cells was measured by western blotting. The expression levels were quantified with ImageJ ( $\mathrm{n}$ $=3$ ). Data are expressed as means $\pm S D .{ }^{*} P<0.05,{ }^{\star} * P<0.01, \star \star * P<0.001$ vs. control. 


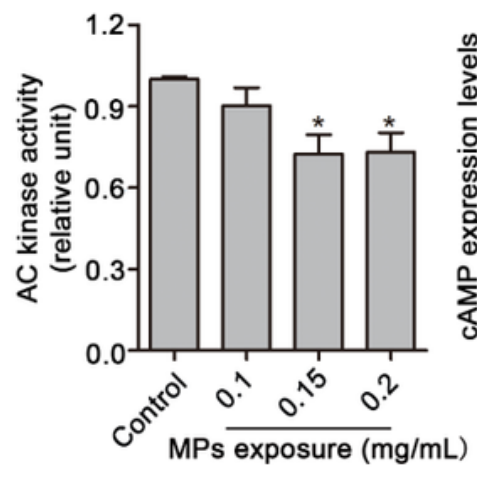

D

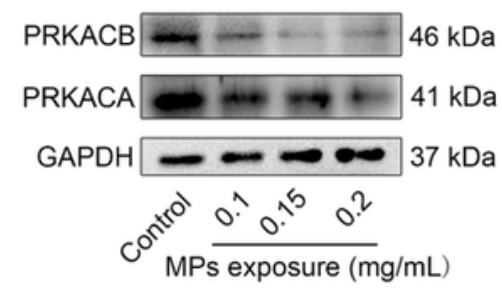

F

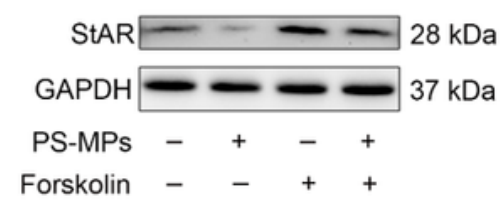

H

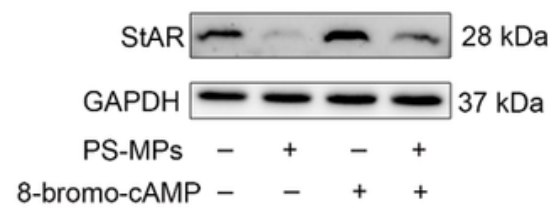

G

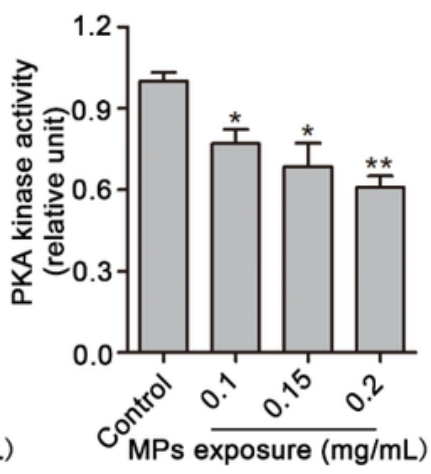

E
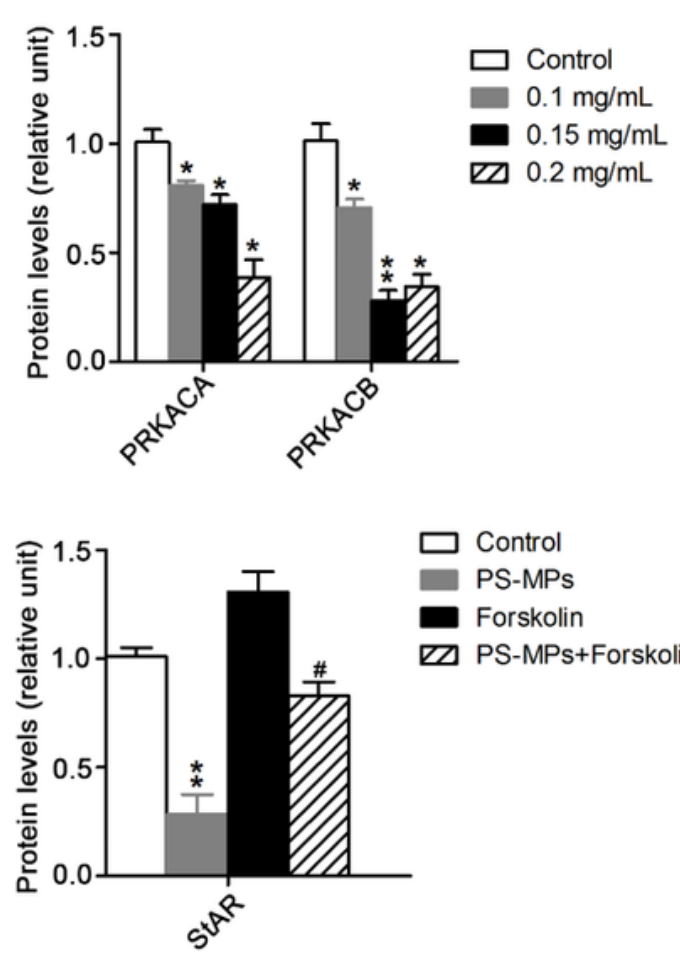

I

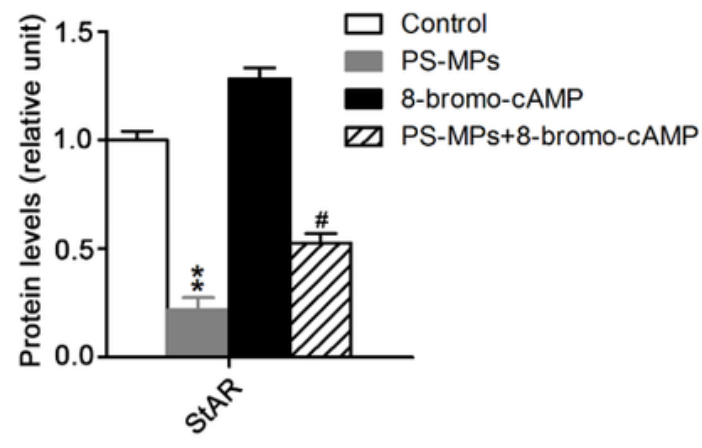

\section{Figure 7}

PS-MPs decreased the level of StAR by inhibiting AC/cAMP/PKA pathway. Primary Leydig cells were exposed to various concentrations of $0.5 \mu \mathrm{m}$ PS-MPs for $24 \mathrm{~h}$. (A) The AC kinase activity was measured by an AC activity assay kit $(n=3)$. Results are expressed as means $\pm S D$. ${ }^{*} P<0.05,{ }^{\star *} P<0.01$ vs. control. (B) The content of cAMP was detected by ELISA $(n=3)$. Results are expressed as means $\pm S D$. $* P<0.05$, ${ }^{\star *} \mathrm{P}<0.01$ vs. control. (C) The PKA kinase activity was examined by a PKA activity assay kit $(n=3)$. 
Results are expressed as means $\pm S D$. ${ }^{*} P<0.05,{ }^{\star} * P<0.01$ vs. control. (D, E) The expression of PRKACA and PRKACB in cells was analyzed by western blotting. The expression levels were quantified with Image $J$ and expressed as means $\pm S D(n=3)$. Results are expressed as means $\pm S D$. ${ }^{*} P<0.05,{ }^{* *} P<0.01$ vs. control. (F, G) Leydig cells were incubated with $0.2 \mathrm{mg} / \mathrm{mL}$ PS-MPs for $1 \mathrm{~h}$ and then cultured in serumfree medium in the presence of $20 \mathrm{mM}$ forskolin for another $24 \mathrm{~h}$. The expression of StAR in cells was analyzed by western blotting. The expression levels were quantified with ImageJ and expressed as means $\pm S D(n=3)$. Results are expressed as means $\pm S D$. ${ }^{*} P P<0.01$ vs. control; $\# P<0.05$ vs. Forskolin treatment group. $(\mathrm{H}, \mathrm{I})$ Leydig cells were incubated with $0.2 \mathrm{mg} / \mathrm{mL}$ PS-MPs for $1 \mathrm{~h}$ and then cultured in serum-free medium in the presence of $0.1 \mathrm{mM}$ 8-bromo-cAMP for another $24 \mathrm{~h}$. The expression of StAR in cells was analyzed by western blotting. The expression levels were quantified with ImageJ and expressed as means $\pm S D(n=3)$. Results are expressed as means $\pm S D$. ${ }^{*} P<0.01$ vs. control; $\# P<0.05$ vs. 8bromo-cAMP treatment group. 
C
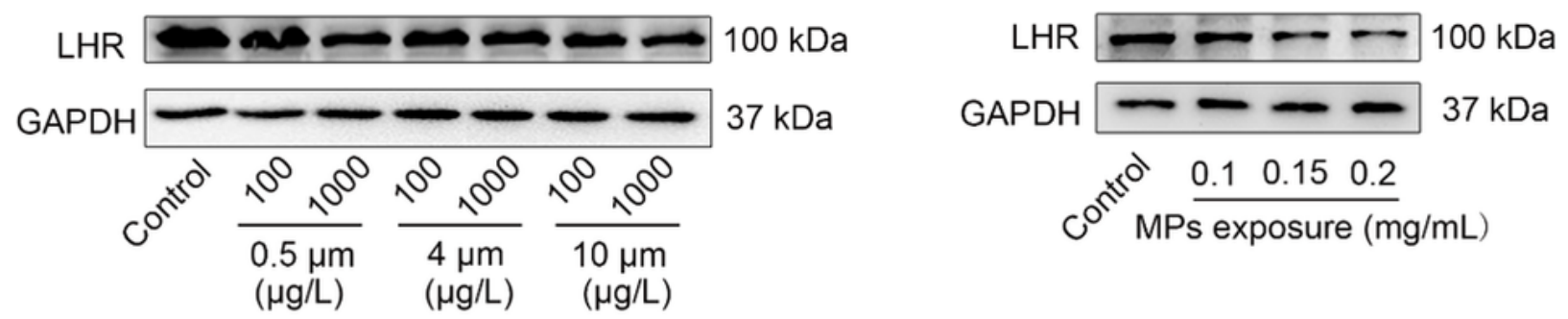

B

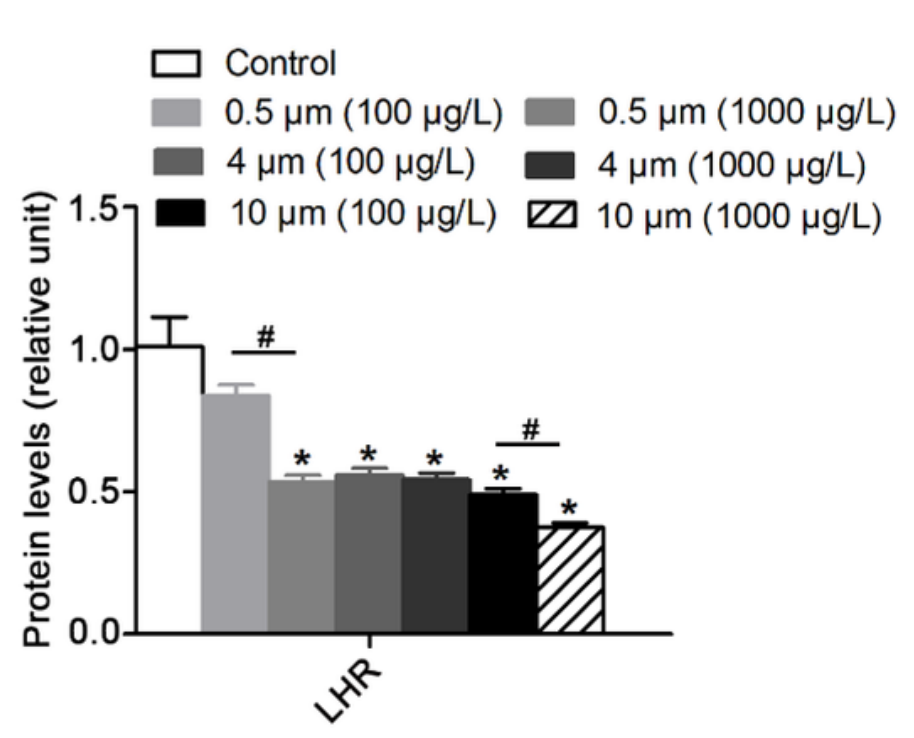

D

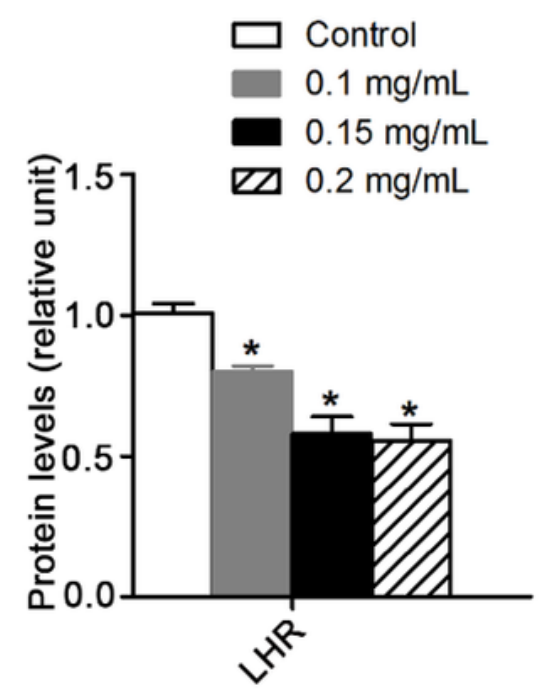

E

$\mathrm{F}$

G
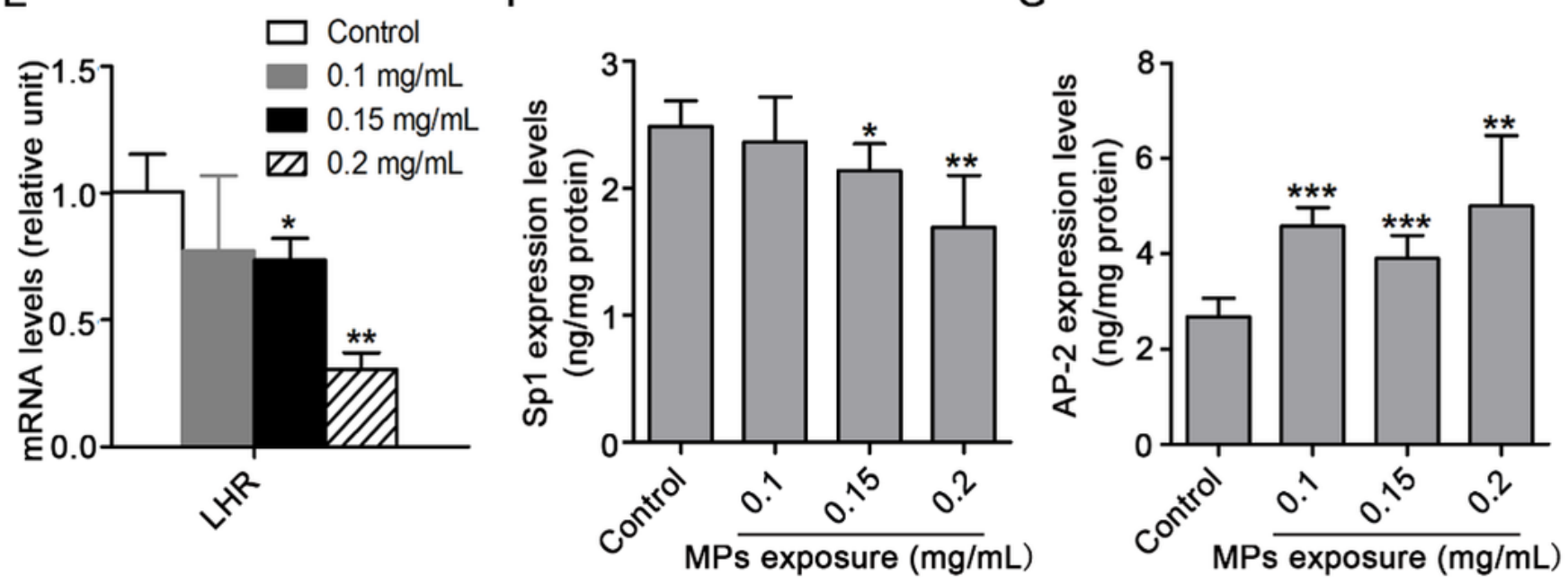

Figure 8

PS-MPs induced a decrease in testosterone levels by reducing LHR level. (A, B) Mice were given drinking water containing various sizes of PS-MPs for 180 continuous days. The expression of LHR in testes was measured by western blotting. The expression levels were quantified with ImageJ and expressed as means $\pm S D$ ( $n=3 ;{ }^{*}<0.05$ vs. control; $\# P<0.05$ vs. $100 \mu \mathrm{g} / \mathrm{L}$ group). (C, D) Primary Leydig cells were exposed to $0.1,0.15,0.2 \mathrm{mg} / \mathrm{mL}$ PS-MPs with a diameter of $0.5 \mu \mathrm{m}$ for $24 \mathrm{~h}$. The expression of LHR in 
cells was analyzed by western blotting. The expression levels were quantified with ImageJ and expressed as means $\pm S D\left(n=3\right.$; ${ }^{*} P<0.05$ vs. control). (E) The mRNA expression levels of LHR in Leydig cells after treatment with PS-MPs were determined by qRT-PCR $(n=3 ; * P<0.05, * * P<0.01$ vs. control). $(F, G)$ The content of Sp1 and AP-2 was detected by ELISA ( $n=3 ;{ }^{*} P<0.05$, ${ }^{\star *} P<0.01$, ${ }^{\star * * P}<0.001$ vs. control).

A

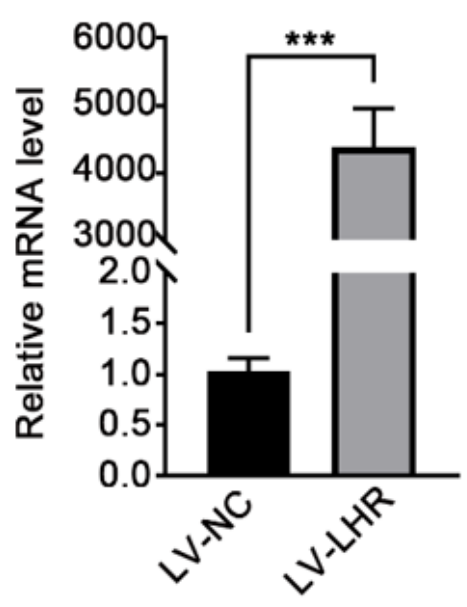

C

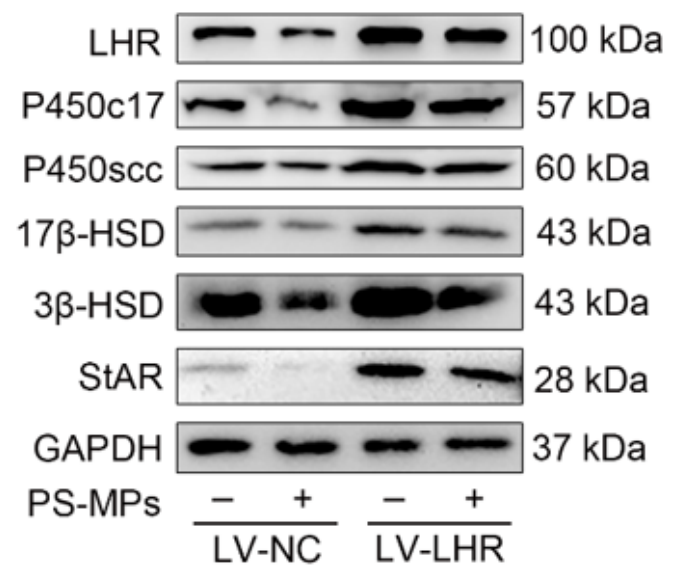

B

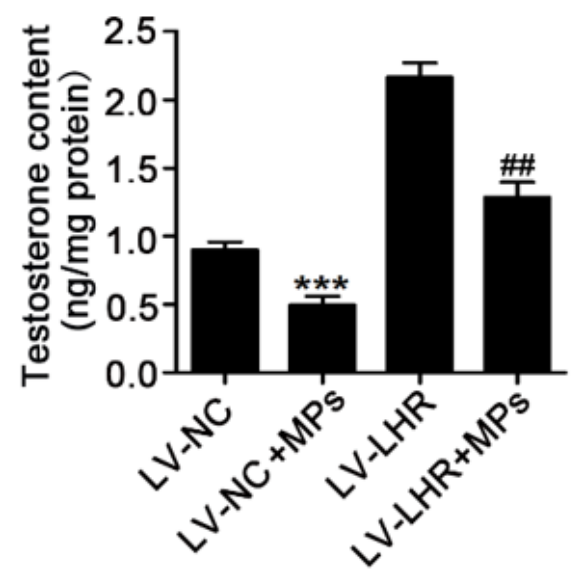

\section{Figure 9}

Overexpression of LHR alleviated the reduction of StAR, steroidogenic enzymes and testosterone levels induced by PS-MPs treatment primary Leydig cells. (A) Primary cells were infected with LHR or Vector with lentivirus for $72 \mathrm{~h}$. The mRNA levels of LHR were tested by qRT-PCR $(n=3 ; \star \star \star P<0.001$ vs. LV-NC group). (B) Primary cells were infected with LHR or Vector with lentivirus for $72 \mathrm{~h}$. Then, the cells were exposed to $0.5 \mu \mathrm{m}$ PS-MPs with a concentration of $0.2 \mathrm{mg} / \mathrm{mL}$ for $24 \mathrm{~h}$. The content of testosterone in supernatant was examined by ELISA $(n=3 ; \star \star \star P<0.001$ vs. LV-NC group; \#\#P $<0.01$ vs. LV-NC+PS-MPs group). (C, D) Primary cells were infected with LHR or Vector with lentivirus for $72 \mathrm{~h}$. Then, the cells were treated with $0.5 \mu \mathrm{m}$ PS-MPs with a concentration of $0.2 \mathrm{mg} / \mathrm{mL}$ for $24 \mathrm{~h}$. The expression of $3 \beta-H S D, 17 \beta-$ HSD, P450scc, P450c17, StAR, and LHR in cells was measured by western blotting. The expression levels were quantified with Image $\left(n=3 ;{ }^{*} P<0.05, * * P<0.01\right.$ vs. LV-NC group; $\# P<0.05, \# \# P<0.01, \# \# \# P<$ 0.01 vs. LV-NC+PS-MPs group). 


\section{Supplementary Files}

This is a list of supplementary files associated with this preprint. Click to download.

- SupplementaryMaterials.docx

- cellimaging.avi 